\title{
Inland populations of Juncus balticus (Juncaceae) in Scotland
}

\author{
Andy Amphlett* \\ Grantown on Spey, Scotland
}

*Corresponding author: Andy Amphlett: amphlett1958@gmail.com

This pdf constitutes the Version of Record published on $13^{\text {th }}$ August 2019

\begin{abstract}
Typically considered a coastal species in Great Britain, Juncus balticus Willd. also occurs inland as a native plant beside the Rivers Avon, Dulnain and Findhorn in NE Scotland (and beside the R. Lossie in the 19th Century). Here it is found at median altitude $290 \mathrm{~m}$ AOD (inter-quartile range, 249 - $341 \mathrm{~m}$ ). It also occurs as a native at one inland loch-side, and was found beside another loch in the 19th Century. In total, J. balticus has been recorded beside inland rivers from $1410 \mathrm{~km}$ grid squares. In its inland riverside habitat, $J$. balticus is overwhelmingly found within communities dominated by native plant taxa, primarily associated with infertile, moist to damp, weakly to moderately acid soils, with high levels of illumination. Few observers are familiar with seeing J. balticus at its inland sites, therefore it is possible that this species has been overlooked along other rivers and burns in NE Scotland, and perhaps elsewhere. The first record of J. balticus beside a road was in 1907, long before roads were widely treated with salt in the winter, but it was not until 1979 that a second roadside population was discovered. Roadside and trackside populations have now been found in $1910 \mathrm{~km}$ grid squares. At most of these sites it is likely to be an accidental introduction. It is now more widespread on roadsides than along inland riversides. The isolated nature of the roadside populations indicates that there have been multiple independent colonisations. It is highly likely that additional roadside populations await discovery, and that further colonisation events will occur.
\end{abstract}

\section{Key Words}

River Avon; River Dulnain; River Findhorn; riverside; roadside; halophyte.

\section{Introduction}

Juncus balticus Willd. was one of the last native Juncus species to be discovered in Britain and Ireland (Pearman, 2017). The first published record from Scotland (Barry Sands, v.c.90) was by Hooker (1821) who wrote, " This highly interesting addition to our northern Flora was discovered in the greatest abundance ... by Mr. Drummond, a most active and intelligent botanist, and zealous naturalist."

In England, J. balticus was the last native rush species to be discovered (Adamson, 1913), "growing in moderate quantity in a damp hollow on the sandhills, locally known as a "slack", near Southport, Lancashire" (v.c.59). Smith (1984) determined that the original locality was $c .600 \mathrm{~m}$ inland from the shore, and that it 
was quite possible that the plant had been overlooked previously, having long been a member of the dune flora but highly localised. E.S. Marshall found J. balticus in a second English locality (Lytham-St Annes, v.c.60) in 1914. This population persisted until 1965, when it was destroyed during the construction of school tennis courts (Smith, 1984).

On the east coast of Scotland, the most southerly populations are in Fife (v.c.85); here there are post-2000 records from Tentsmuir. On the west coast, the most southerly populations are at Oldshoremore (v.c.108). There is also a 19th century record from 'near' Scourie, c.15 km further south. Remarkably there are no records further south along the west coast of mainland Britain until you reach the Lancashire population. Juncus balticus is found along the whole length of the Outer Hebrides (v.c.110) and on Tiree (v.c.103). It was reported from Sanday, Orkney (v.c.111) in 1996, but that record has not been confirmed. In 1997 it was found at Sandside Bay on the east of Mainland, Orkney, at its most northerly location in Great Britain.

Juncus balticus has now been recorded from $9910 \mathrm{~km}$ grid squares (hectads) in Scotland and from 3 hectads (one a failed introduction) in England (Fig. 1). It has been recorded from 80 hectads since 1987 (65 hectads post-1999). There are no records from Wales, Ireland or the Channel Islands.

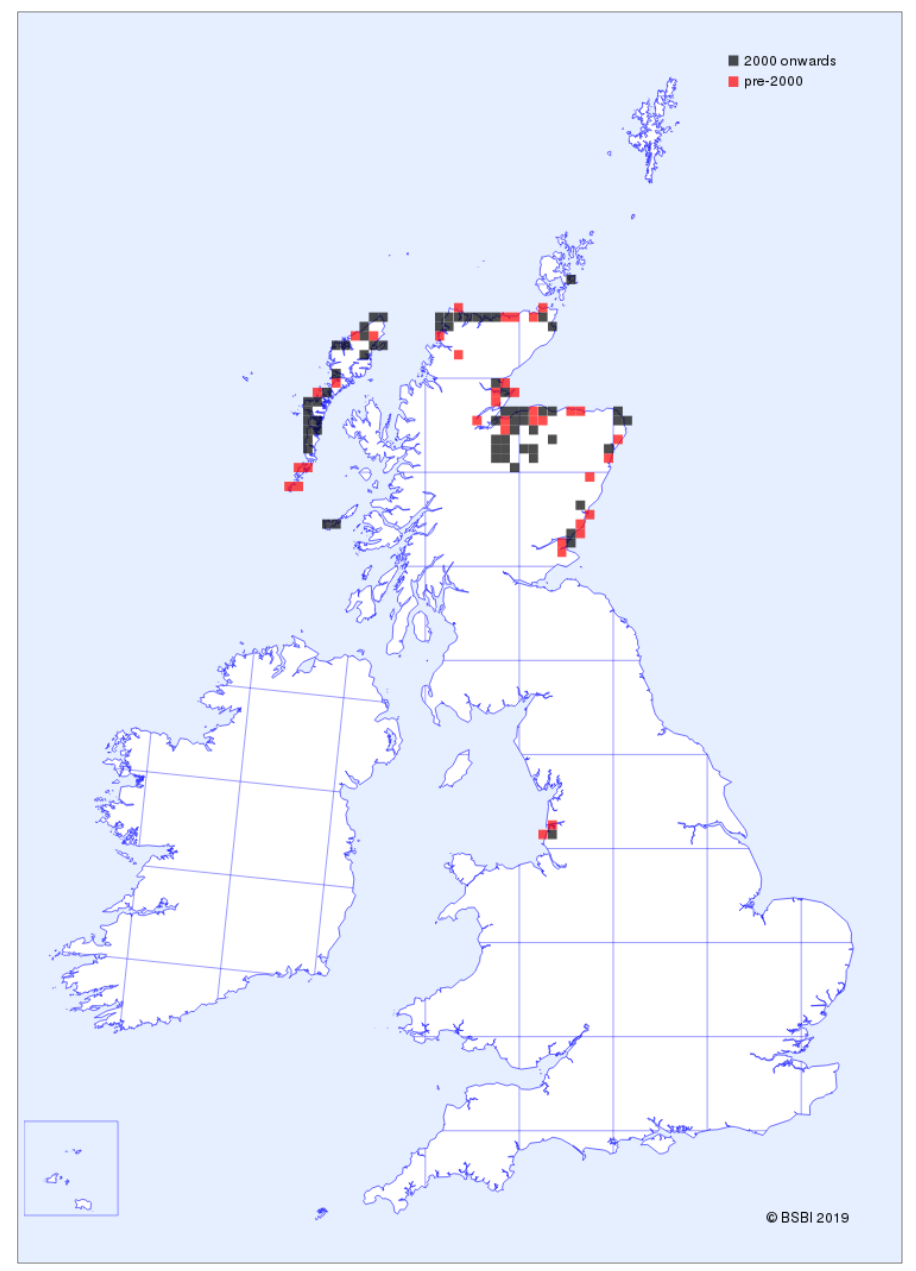

Figure 1. Juncus balticus hectad distribution, pre-2000 (red) and post-1999 (black). From BSBI Distribution Database (DDb) January 2019. 
Juncus balticus typically forms diffuse patches with stems growing from a creeping rhizome, rather than in dense tufts. Stems are dark green, up to $c .50 \mathrm{~cm}$ tall (occasionally more), narrow, perfectly smooth when fresh, firm when squeezed and often slightly sinuous. Inflorescences appears lateral, and are lax, with ascending branches. While many of the inland populations of $J$. balticus comprise plants with typical jizz, there also occur some plants that grow in atypically dense patches. Such plants are easily overlooked. Conversely, some forms of J. effusus can be very similar to J. balticus. Patterns of stem stomata (Amphlett, 2018) provide an additional ID feature differentiating these two species.

\section{Broad habitats analysis}

All records on the BSBI Distribution Database (DDb), at December 2018, were examined, and sites allocated to four broad habitat groupings, based on locality type (Table 1, Fig. 2). In 12 hectads J. balticus occurs in two broad habitat types, hence the cumulative hectad total (114) exceeds the number of unique hectads (102).

Table 1. Juncus balticus. Broad habitats.

\begin{tabular}{|l|l|}
\hline Broad habitat & $\begin{array}{l}\text { Number of } \\
\text { hectads }\end{array}$ \\
\hline $\begin{array}{l}\text { Coastal and near } \\
\text { coastal }\end{array}$ & 79 \\
\hline Inland riverside & 14 \\
\hline Road \& track verge & 19 \\
\hline Other & 2 \\
\hline
\end{tabular}

\section{Coastal and near coastal sites}

By the end of the 19th century, coastal and near coastal populations of J. balticus had been discovered in 24 hectads, and in 60 hectads by the close of fieldwork for the first Atlas (Perring and Walters, 1962). It was discovered in four additional hectads per decade from the 1960s to the 1990s, and post-1999 it has been found in a further three hectads.

Coastal and near coastal habitats are described by Stace (in Stewart et al, 1994) and Smith (1984). Here, plants grow in dune slacks and other damp areas in maritime sand, mud or peat. Plants may grow in areas inundated by the highest tides, eg at Kingsteps, Nairn (v.c.96), (NH9057) (Fig. 3), as well as up to $1.5 \mathrm{~km}$ inland (Tiree, v.c.103), (eg. NM0045), almost always in sites influenced by sea water or spray. Plants near Spynie (v.c.95), (NJ2166 and NJ2266), grow c.4 km inland, but these are considered a relict coastal population; in medieval times the nearby Loch Spynie was an inlet of the sea. The population at Kingsteps (Fig. 3) extends over c.2 hectares, and well displays the characteristic appearance of aerial stems forming straight lines or diffuse patches, arising from extended rhizomes. 


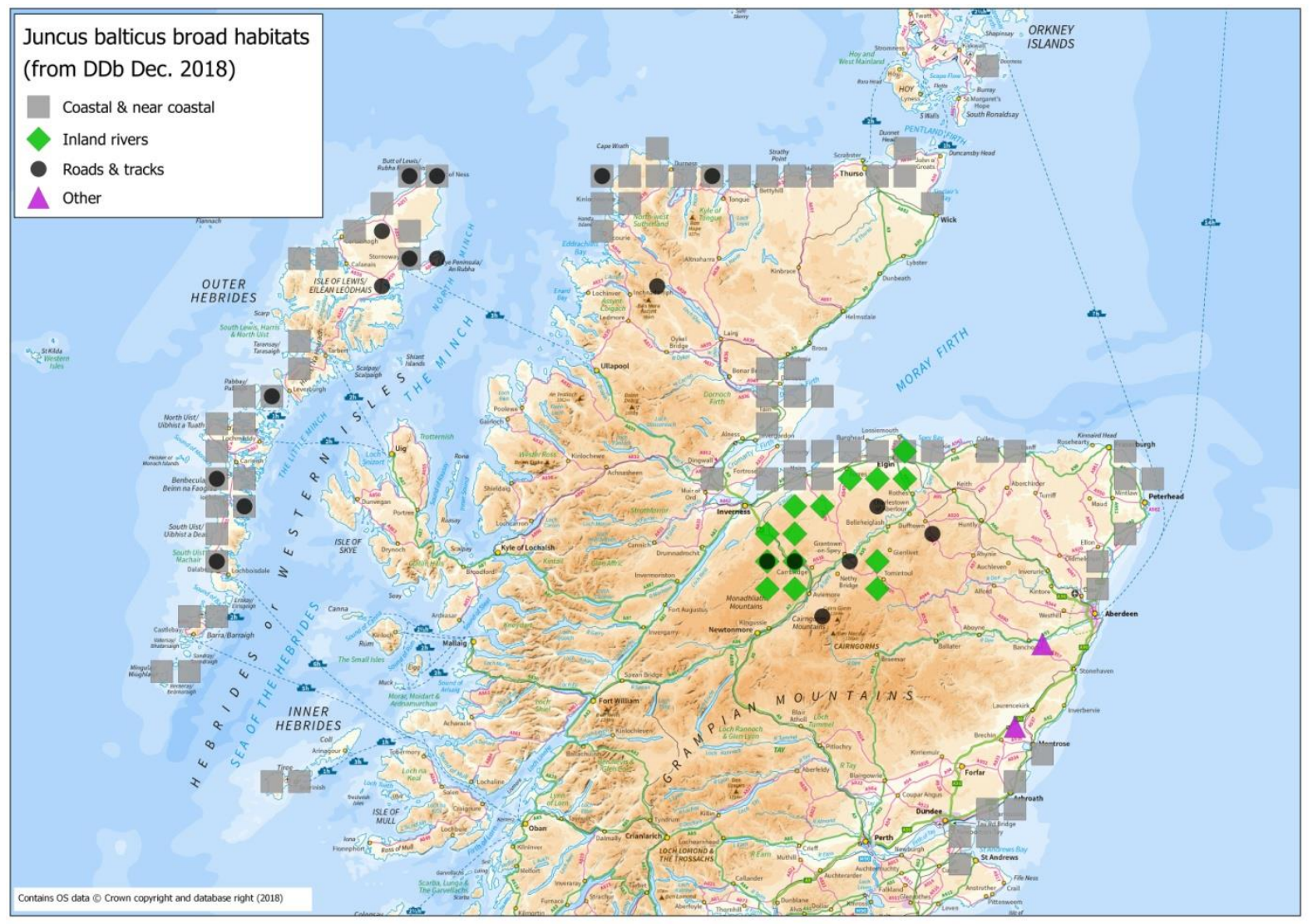

Figure 2. Juncus balticus hectads x broad habitats.

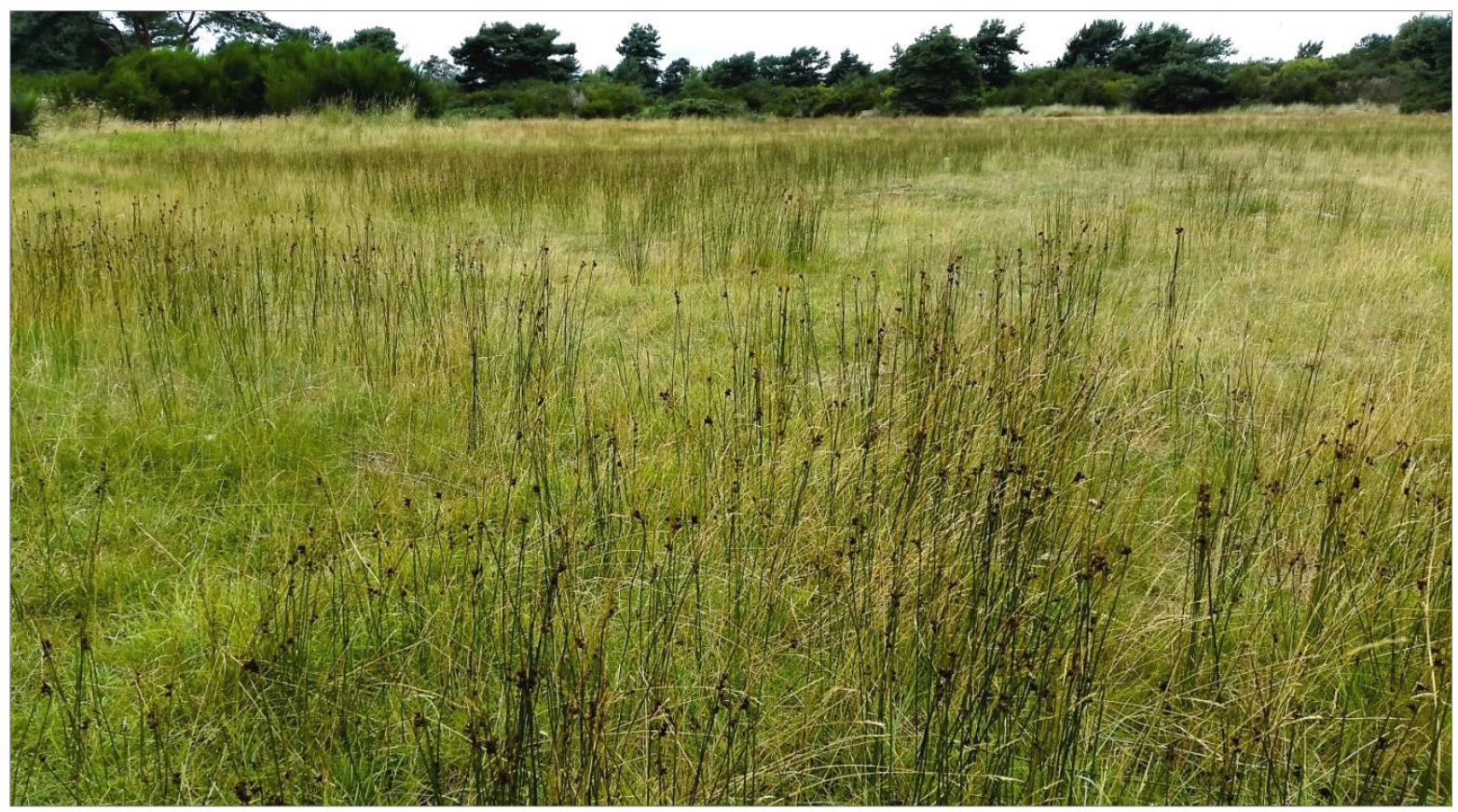

Figure 3. Juncus balticus at Kingsteps, Nairn (v.c.96). 


\section{Inland riverside sites}

The discovery of inland, riverside populations of J. balticus is summarised in Fig. 4. In 1832, W.A. Stables found J. balticus in three hectads along two rivers in N.E. Scotland, the Rivers Lossie and Findhorn. In 1954, Mary McCallum Webster found it beside the R. Avon; in 1968 beside the Glenmazeran Burn, a tributary of the R. Findhorn; in 1972 by the R. Dulnain; and in 1975 by the Allt Bruachaig, another Findhorn tributary. In 1998, Ian Green found it by the Bogbain Burn, a tributary of the R. Dulnain.

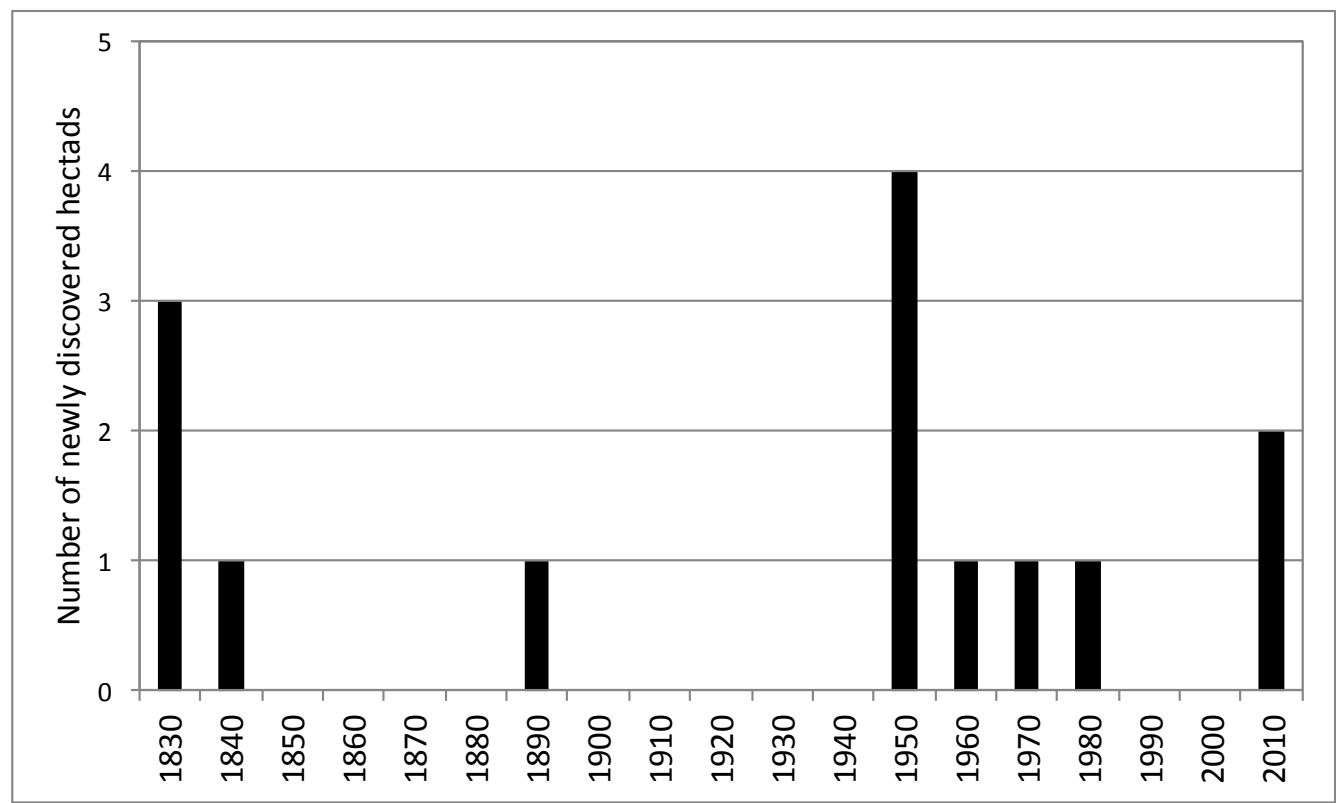

Figure 4. Juncus balticus. Number of newly discovered inland riverside populations (hectads per decade)

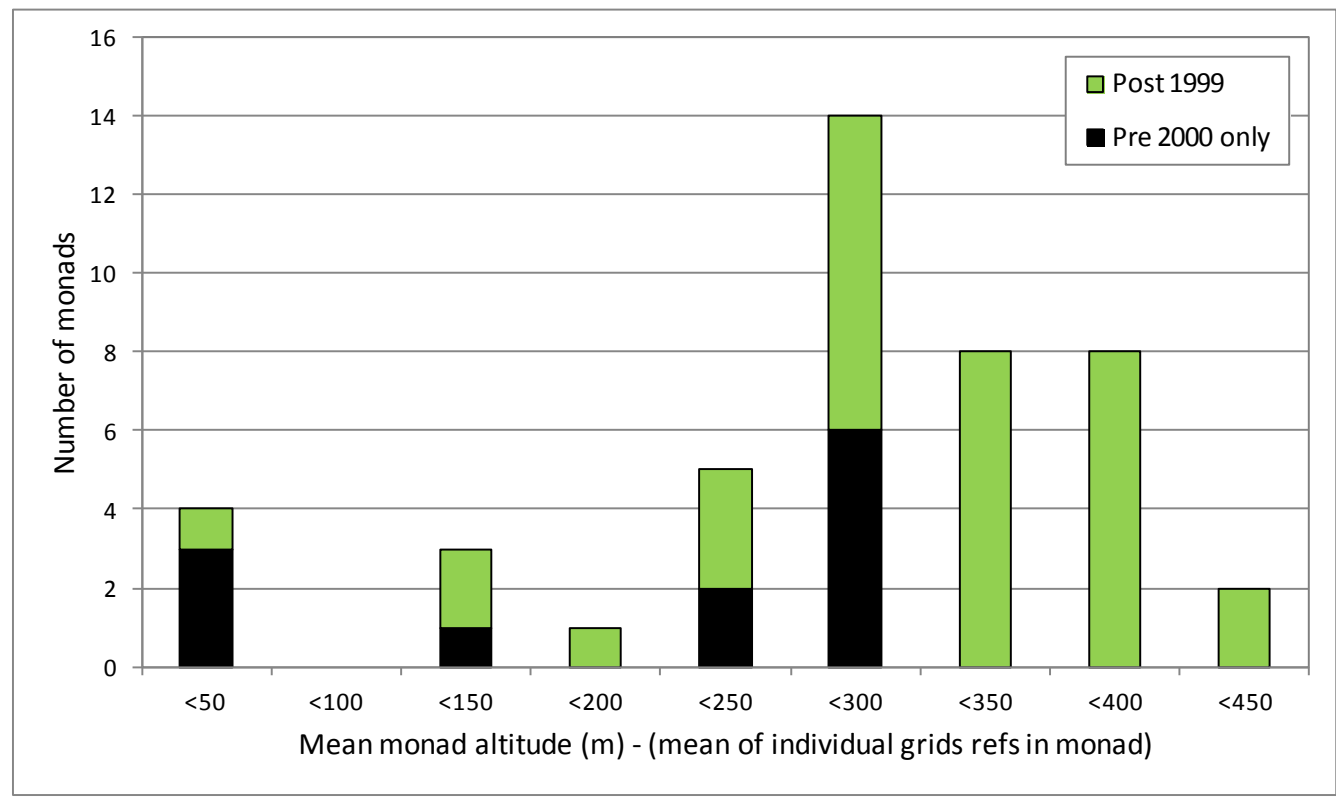

Figure 5. Juncus balticus, inland riverside populations. Number of monads $\times 50 \mathrm{~m}$ altitude bands. 
The altitude of each recorded location along inland rivers was estimated from OS 1:25,000 scale maps. The mean altitude of locations in each one $\mathrm{km}$ grid square (monad) were calculated, and assigned to $50 \mathrm{~m}$ altitude bands (Fig. 5).

The monad distribution of $J$. balticus alongside inland rivers is shown in Fig. 6 and summarised, below, by altitudinal bands. Unless otherwise stated, all records are post-1999. Inland riverside populations of J. balticus range in altitude from $10 \mathrm{~m}$ to $425 \mathrm{~m}$ AOD. Median (of the mean monad altitudes) is $290 \mathrm{~m}$ (inter-quartile range, $249-341 \mathrm{~m})$.

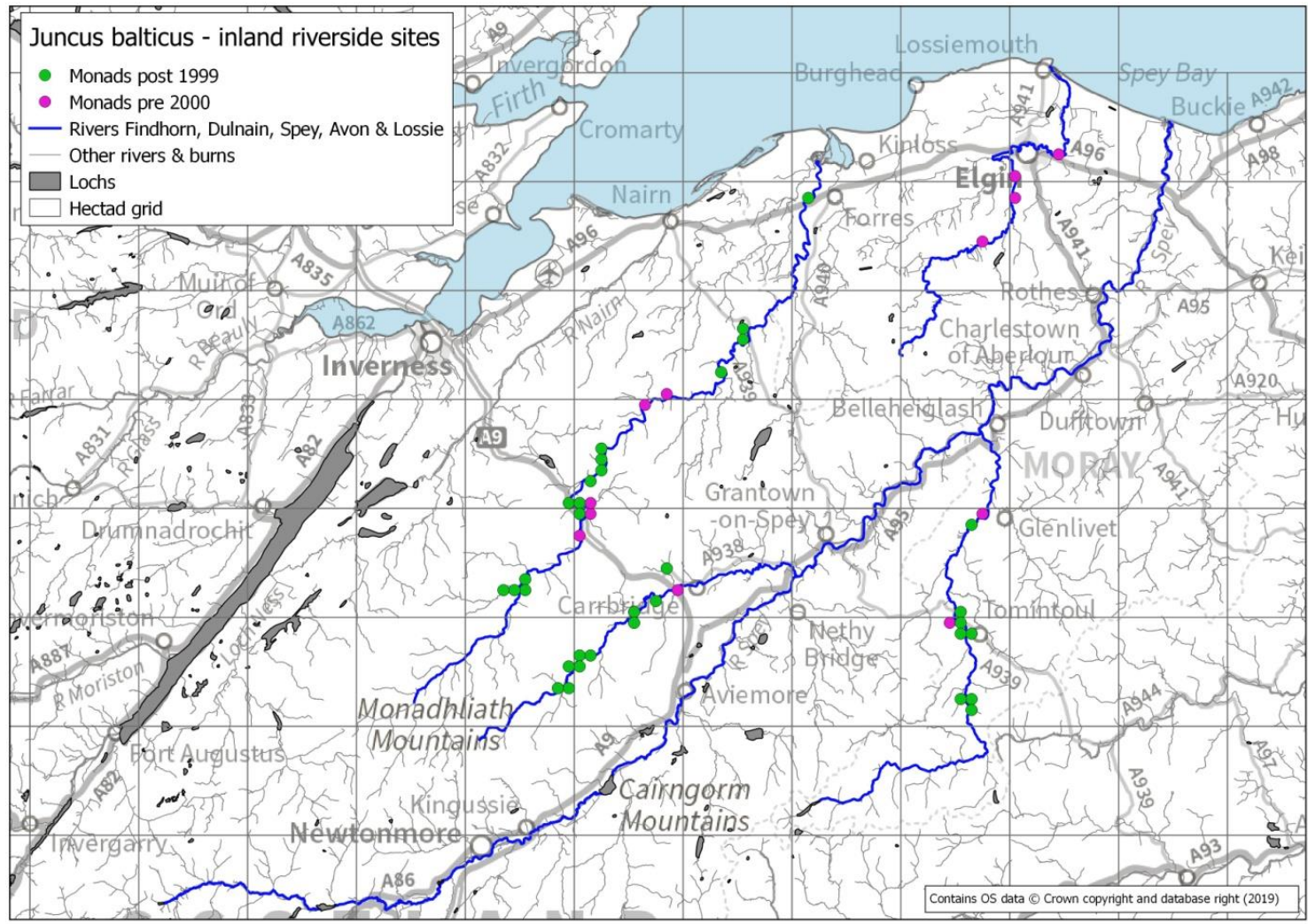

Figure 6. Juncus balticus, monad distribution along inland rivers in NE Scotland.

\section{0-100 m AOD}

The only extant locality below $100 \mathrm{~m}$ AOD is at Bridge of Findhorn (NJ0158). Here, the presence of $J$. balticus is considered most likely to be a result of transport of rhizomes or seed from populations further upstream, rather than dispersal from (downstream) coastal populations. The other low altitude sites were by the R. Lossie, and have not been seen since the first half of the 19th century.

In 2016, Mick Crawley found J. balticus beside the Morvich Burn (v.c.107, $\mathrm{NH7699)}$ within the Mound Alderwood SAC / SSSI at $<5 \mathrm{~m} \mathrm{AOD.} \mathrm{The} \mathrm{plants} \mathrm{were} \mathrm{in}$ a rushy open area in the spate zone of the burn, c.1.5 km from the tidal Loch Fleet. The alder woodland here developed after the inner part of Loch Fleet was enclosed by the Mound embankment in 1816. There are no known populations of J. balticus upstream of this location, and the population is therefore considered to be a relict coastal one. 


\section{1-200 m AOD}

Between 101 and $200 \mathrm{~m}$ AOD there are three extant locations along the R. Findhorn, each comprising no more than two small clumps or patches, growing at the very edge of the river in the spate zone (Fig. 7). These small populations may be very persistent. Plants were first found near Ardclach in 1898, and re-found at much the same spot (in NH9545) in 2018. Near Logie Bridge (NH9546), plants were found in 1960 and 1964, then re-found in 2018.

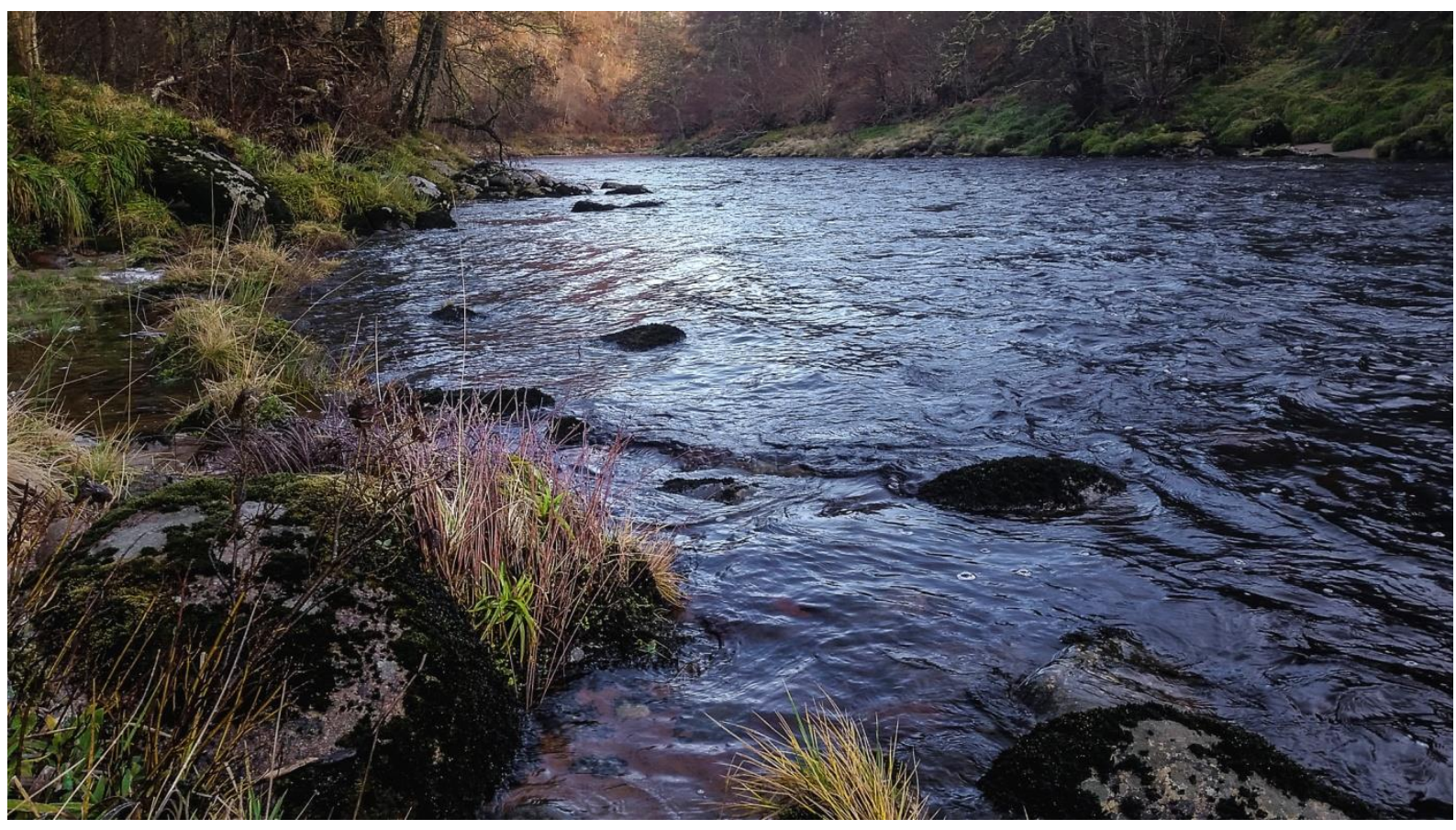

Figure 7. Juncus balticus (brown stems beside large rounded rock in foreground), growing beside River Findhorn at Ardclach (v.c.96).

\section{1-250 m AOD}

Between 201 and $250 \mathrm{~m}$ AOD along the R. Findhorn, the first significant population is found at Shenachie (NH8235), on the west bank of the river at $250 \mathrm{~m} \mathrm{AOD.} \mathrm{Found}$ here by Mary McCallum Webster in 1954, it was re-found in 2017, and occurs in seven $100 \mathrm{~m}$ OS grid cells. Along the R. Avon, the two lowest altitude populations are at around $200-210$ m AOD, (NJ1628, and (in 1971) NJ1729).

\section{1-300 m AOD}

Between 251 and 300 m AOD, J. balticus occurs along three rivers. In 2017 it was recorded in 13100 m grid cells along the east and north banks of the R. Findhorn, with the most frequent stands to the west of Inverbrough in monads NH7930, NH8030 and NH8029. It was here that Stables first found it in 1832. Beside the R. Dulnain it first appears, near Sluggan, NH8721, at 285 m AOD, though in 1972 Mary McCallum Webster found "very robust plants" by the R. Dulnain in NH8922, at $270 \mathrm{~m}$ AOD. These were growing in tall vegetation, with Cirsium heterophyllum, Valeriana officinalis, Alnus glutinosa. On the R. Avon, there are a few patches on shingle in $\mathrm{NH} 1520$, and in $\mathrm{NH} 1519$ the northernmost plants of a very large population are 
found just below the $300 \mathrm{~m}$ contour. In 1983, Mary McCallum Webster recorded

"very robust $3 \mathrm{ft}$. plants on edge of $R$. Avon" in NJ1419 at 290 m AOD.

\section{1-350 m AOD}

Between 301 and $350 \mathrm{~m} \mathrm{AOD,} \mathrm{J}$. balticus is again found along the same three rivers, as well as at a single location beside the Bogbain Burn, a tributary of the R. Dulnain. By the Bogbain Burn, NH8824 at 320 m AOD, there is a single patch of $c .300$ stems in a strip of poor fen between a bog and the burn. Here, Galium uliginosum is an abundant associate. Other species growing close by are: Achillea ptarmica, Agrostis canina, Caltha palustris, Carex nigra, C. rostrata, Cirsium palustre, Comarum palustre, Deschampsia cespitosa, Equisetum palustre, E. arvense, Erica tetralix, Heracleum sphondylium, Holcus lanatus, H. mollis, Juncus conglomeratus, J. effusus, Pinus sy/vestris, Ranunculus acris, Rumex acetosa, Salix aurita $x$ cinerea $=S . x$ multinervis, Silene flos-cuculi, Succisa pratensis and Viola palustris.

By the R. Dulnain a few stems grow in two locations at $315 \mathrm{~m} \mathrm{AOD,} \mathrm{on} \mathrm{shingle}$ and in a damp grassy area, in monads NH8519 and NH8520. West of Tomintoul, NJ1518 and NJ1618, (Fig. 8), J. balticus is found in $14100 \mathrm{~m}$ OS grid cells along the west side of the R. Avon between c.295 - 305 m AOD. This population was surveyed in detail in 2005, and over 8000 flowering / fruiting stems were counted. Here it is found in association with Equisetum variegatum, growing close to the edge of the river, in a mosaic of shifting channels. Beside the R. Findhorn, at $340 \mathrm{~m} \mathrm{AOD,} J$. balticus occurs in 4 OS $100 \mathrm{~m}$ grid cells on the west side of the river, at and a short distance north of its junction with the Glenmazeran Burn (NH7422 and NH7522). Suitable habitat extends upstream along the R. Findhorn for $c .10 \mathrm{~km}$, but despite extensive searches, no additional populations of $J$. balticus have been found beyond this point.

\section{Above $350 \mathrm{~m} A O D$}

At altitudes greater than $350 \mathrm{~m} \mathrm{AOD}, J$. balticus occurs beside the Rivers Avon and Dulnain, and by the Glenmazeran Burn.

Mary McCallum Webster found J. balticus in Glenmazeran (NH7322) in 1968, and Clive Stace recorded it here in August 1972. Stace (pers. comm.) noted that it grew in wet marshy places a few yards from the river bank, $c .1 .5 \mathrm{~m}$ above river level, in dense lush grassy-rushy vegetation, mixed with J. effusus. Soils comprised very wet peaty topsoil, over sand and shingle. The water table was at +4 to $-65 \mathrm{~cm}$. Some specimens grew in drier places on higher ground, where the water table down to $-100 \mathrm{~cm}$. It was again recorded here in 2018 in two OS $100 \mathrm{~m}$ grid cells at $375 \mathrm{~m}$ AOD. Suitable habitat extends for over $2 \mathrm{~km}$ along the burn, but only a limited search was possible in 2018. Stace's account (in Stewart et al 1994) refers to $J$. balticus growing on river terraces or flood-plains at up to c.400 m AOD on Slochd Mor. However the habitat and associated species he describes refers to the Glenmazeran site, c.11 km WSW of Slochd Mor (Stace pers. comm.). Plants of $J$. balticus do grow as high as $390 \mathrm{~m}$ AOD near the Slochd, but they are on a road verge (see below). There is a 1972 record by Mary McCallum Webster from a 'bog in gully' at Slochd. She only gave a hectad grid reference, but from the site description, may have been in NH8424, at c.350 m AOD. 


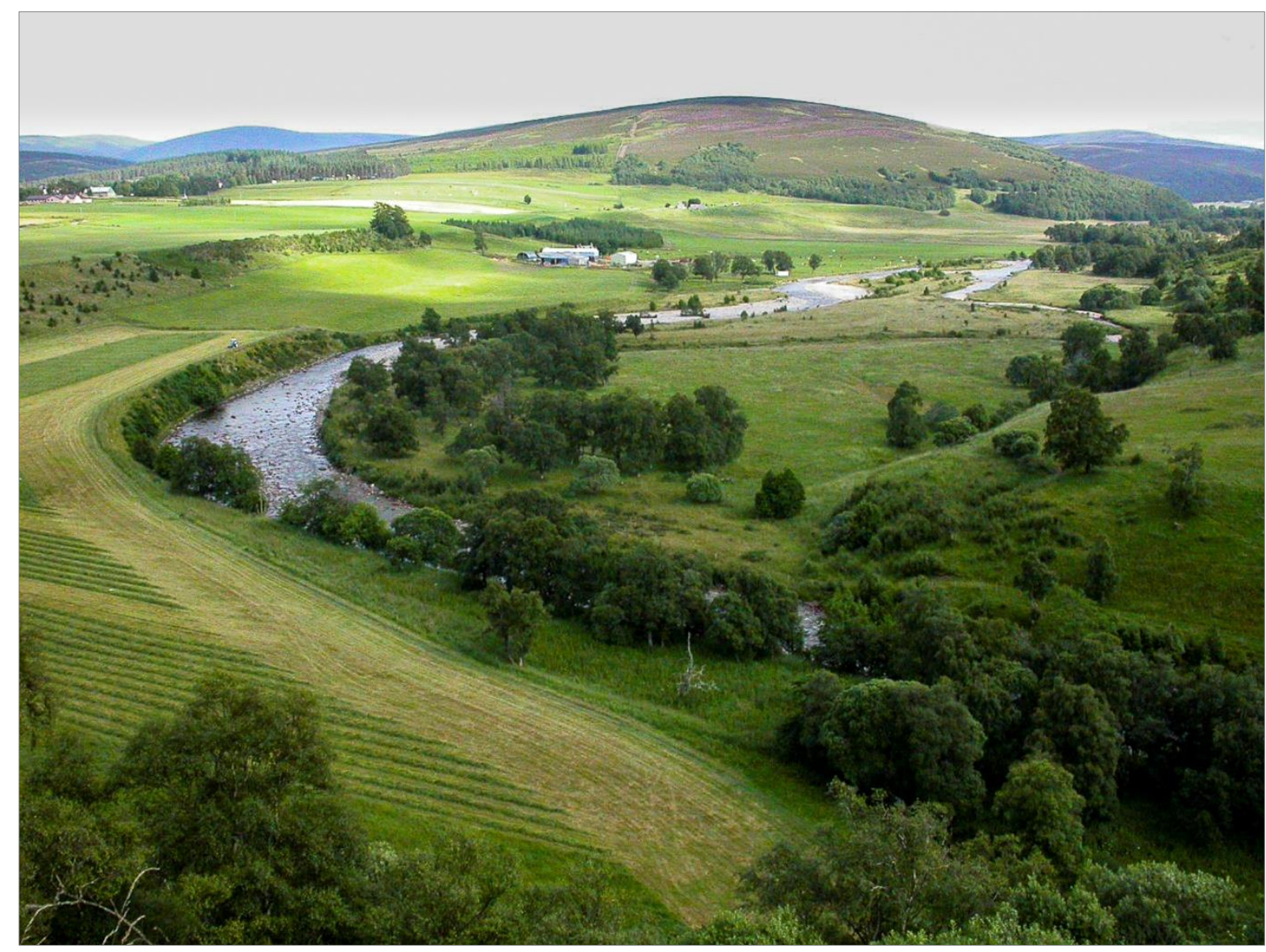

Figure 8. River Avon west of Tomintoul (v.c.94). A very large population of $\boldsymbol{J}$. balticus grows beside the river here (in the middle distance).

Two overnight backpacking trips were undertaken to the upper reaches of the R. Dulnain, in 2017 and 2018, specifically to search for J. balticus. The rush was discovered in nine OS $100 \mathrm{~m}$ grid cells between $370 \mathrm{~m}-425 \mathrm{~m} \mathrm{AOD}$, along $4 \mathrm{~km}$ of river floodplain, south-west of Caggan Bridge. This scattered population was previously unknown. Plants grow in short grassland along the river bank and beside old former channels of the braided river (Fig. 9). 78 vascular plant taxa were recorded within the same nine OS $100 \mathrm{~m}$ grid cells; the most notable (and locally frequent) associate here is Viola canina. The plants growing at $425 \mathrm{~m} \mathrm{AOD}$ are the highest altitude, native population in Scotland.

On the west side of the R. Avon, J. balticus occurs at $360 \mathrm{~m} \mathrm{AOD}$, in three OS $100 \mathrm{~m}$ grid cells below Na Tri Chaochain (NJ1512, NJ1612 and NJ1611), at its highest location along this river. 59 vascular plant taxa were recorded within the same three OS $100 \mathrm{~m}$ grid cells; the most notable species were Carex capillaris, $E$. variegatum (a large population) and Potentilla crantzii.

\section{Taxon co-occurrences}

In total, J. balticus has been recorded beside inland rivers, post-1999, from 62100 $\mathrm{m}$ grid squares, in 33 monads. The majority of $100 \mathrm{~m}$ grid squares (51) were recorded by the author, the remainder by Ian Green, either with the author or working alone. Detailed quadrat lists of associate species have not been made at 
riverside sites. However, in the course of wider plant recording, 212 other plant species and hybrids have been recorded (post-1999) within these same $62100 \mathrm{~m}$ grid squares. These taxon co-occurrences give a good impression of the botanical context within which $\mathrm{J}$. balticus occurs.

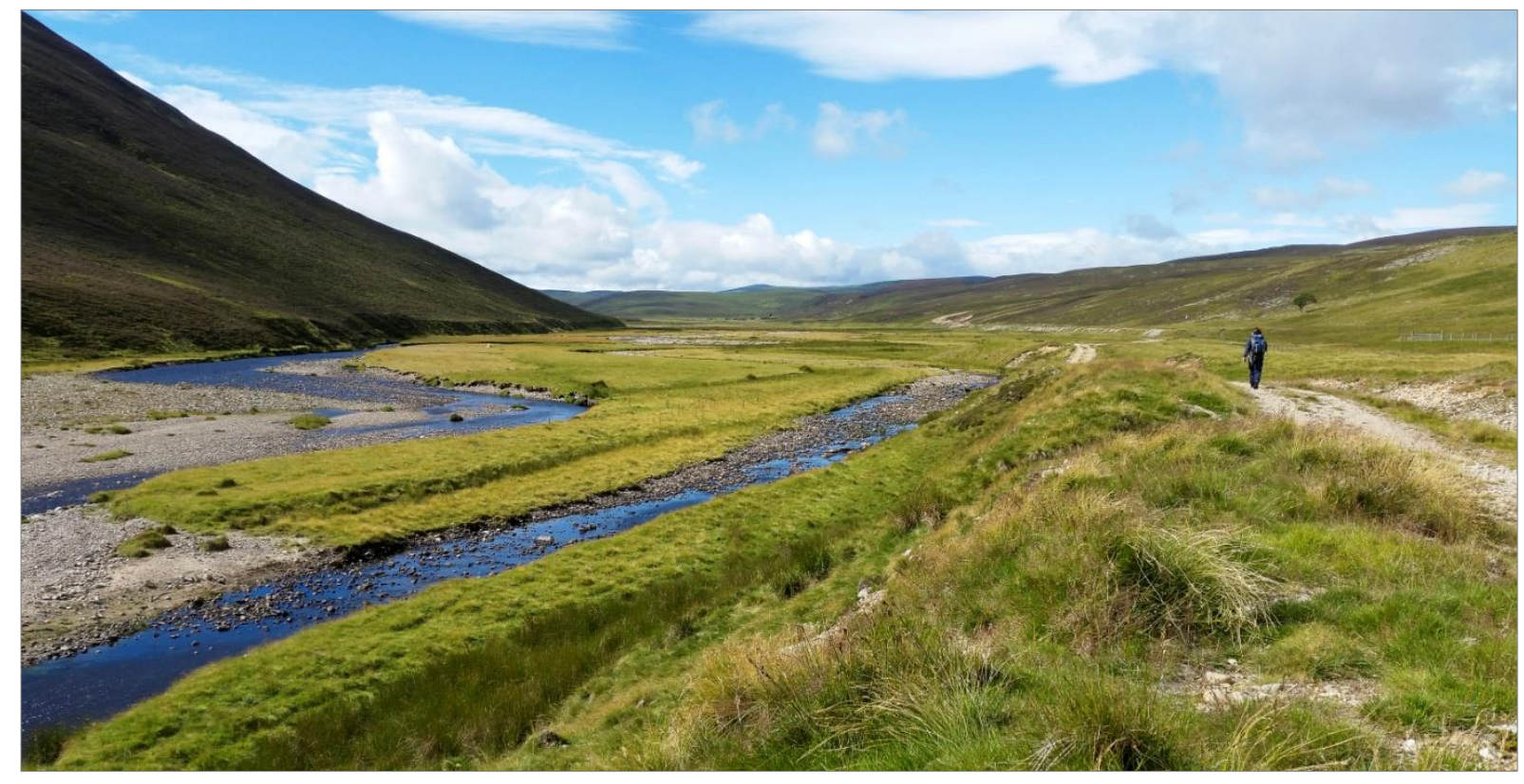

Figure 9. River Dulnain (v.c.96), overview of habitat of J. balticus.

In its inland riverside habitat, $J$. balticus is overwhelmingly found within communities dominated by native plant taxa. Of the 212 associated taxa, 205 are GB natives (199 v.c. natives) and seven are GB aliens (13 v.c. aliens), and 204 associated taxa have Ellenberg values (Hill et al, 2004); Table 2.

Table 2. Number of taxa per Ellenberg value, recorded (post-1999) in same 100 $\mathrm{m}$ grid cells as post-1999 records of Juncus balticus at inland riverside sites. Median values (green shaded cells). Modal values (blue font).

\begin{tabular}{|r|r|r|r|r|r|}
\hline Ellenberg value & Moisture & Light & Nitrogen & Reaction & Salt \\
\hline 0 & & & & & $\mathbf{1 8 7}$ \\
\hline 1 & 0 & 0 & 7 & 0 & 14 \\
\hline 2 & 1 & 0 & $\mathbf{5 2}$ & 13 & 2 \\
\hline 3 & 2 & 1 & 36 & 15 & 0 \\
\hline 4 & 14 & 8 & 34 & 27 & 1 \\
\hline 5 & $\mathbf{5 8}$ & 27 & 32 & 42 & 0 \\
\hline 6 & 51 & 28 & 28 & $\mathbf{6 7}$ & 0 \\
\hline 7 & 21 & $\mathbf{8 8}$ & 10 & 34 & 0 \\
\hline 8 & 25 & 47 & 4 & 6 & 0 \\
\hline 9 & 23 & 5 & 1 & 0 & 0 \\
\hline 10 & 7 & & & & \\
\hline 11 & 1 & & & & \\
\hline 12 & 1 & & & & \\
\hline
\end{tabular}




\section{Moisture}

Only $1 \%$ of taxa are dry site indicators (values 1 or 2 ), while $53 \%$ of taxa are moist site indicators (values 5 or 6 ). $38 \%$ of taxa are found in constantly damp or wetter sites (values 7 or more).

\section{Light}

Sixty-nine\% of taxa are associated with high light levels (values of 7 or more), while only $18 \%$ are associated with semi-shade to shaded conditions (values of 5 or less).

\section{Nitrogen}

Modal value is 2 (infertile sites) and only $7 \%$ of taxa have $\mathrm{N}$ values of 7 or more, signifying a preference for richly fertile sites.

\section{Reaction}

$48 \%$ of taxa are associated with moderately acid to acid conditions (values 5 or less). $50 \%$ of taxa are associated with weakly acid to weakly basic conditions (values 6 and 7 ). Only $3 \%$ of taxa are associated with basic conditions (value 8 ).

Salt

Ninety-two\% of associated taxa are absent from saline sites, and $8 \%$ of taxa are salt tolerant though not preferentially associated with saline sites (values 1 or 2). Only a single species is preferentially associated with saline conditions, Cochlearia danica. However this is a recording artefact of using $100 \mathrm{~m}$ grid square, $C$. danica being on the verge of the A96, while J. balticus is nearby on the bank of the River Findhorn, at Findhorn Bridge.

\section{Summary}

Juncus balticus in its native inland riverside sites is found growing with taxa that are primarily associated with infertile, moist to damp, weakly to moderately acid soils, with high levels of illumination. Comparison with the published Ellenberg values (Hill et al, 2004), (Table 3), indicates that in its inland riverside sites, J. balticus may be slightly more shade tolerant, occurs in drier sites, which are slightly less acid, slightly more fertile and that have no saline influence.

Table 3. Juncus balticus Ellenberg values (from Plantatt) cf median and modal Ellenberg values of taxa recorded (post-1999) in same $100 \mathrm{~m}$ grid cells as post1999 records of $J$. balticus at inland riverside sites.

\begin{tabular}{|l|l|l|l|l|l|}
\hline & Moisture & Light & Nitrogen & Reaction & Salt \\
\hline Plantatt (Hill et al, 2004) & 8 & 8 & 2 & 5 & 1 \\
\hline Inland riverside (Median) & 6 & 7 & 4 & 6 & 0 \\
\hline Inland riverside (Mode) & 5 & 7 & 2 & 6 & 0 \\
\hline
\end{tabular}

\section{Roadside sites}

Juncus balticus is now known to occur beside roads in vice-counties 94, 95, 96, 107, 108 and 110, and beside a moorland track in v.c.108.

It is tempting to assume that $J$. balticus is occupying the same niche as numerous other roadside halophytes. However, the first record of J. balticus beside a road was made by Trail in 1907 , long before roads were widely treated with salt in 
the winter. He wrote "In August of this year, while residing at Aviemore, I walked from the railway station at Daviot by Moy and Tomatin to Carrbridge. Between the last two, the road crosses a range of hills, and ... passes through a ravine, known as Slochd Mor ... Near a milestone marked Carrbridge $6^{1} / 2$ miles where the altitude must approach $1300 \mathrm{ft}$ grow several clumps of Juncus balticus. Two or three of these are some feet across and of vigorous growth so that the conditions appear to be very favourable despite the altitude and the distance from the sea-coast" (McCallum Webster, 1978).

I have failed to relocate the milestone referred to by Trail, but it is marked on the 1904 edition of the Ordnance Survey 6 inch to 1 mile scale map (viewable on the National Library of Scotland website). The location was visited in 2014, and $J$.

balticus was found to occur within 21 OS $100 \mathrm{~m}$ grid cells, along $1.7 \mathrm{~km}$ of this road, between 338 - $390 \mathrm{~m}$ AOD (Figs. 10 and 11). Here, plants grow in a narrow zone adjacent to the road. Other halophytes occurring along the same length of road are Plantago maritima, Puccinellia distans, Sagina maritima and Spergularia marina. If Trail found the only plants along this road in 1907, then over the following century $J$. balticus spread $c .1 \mathrm{~km}$ to the north-west (downhill), and $c .700 \mathrm{~m}$ to the east southeast (uphill). The population here is discontinuous, so spread must have been by both seed dispersal and rhizome extension. The greater spread downhill, perhaps suggests that dispersal is aided by runoff after rain and periods of snow melt.

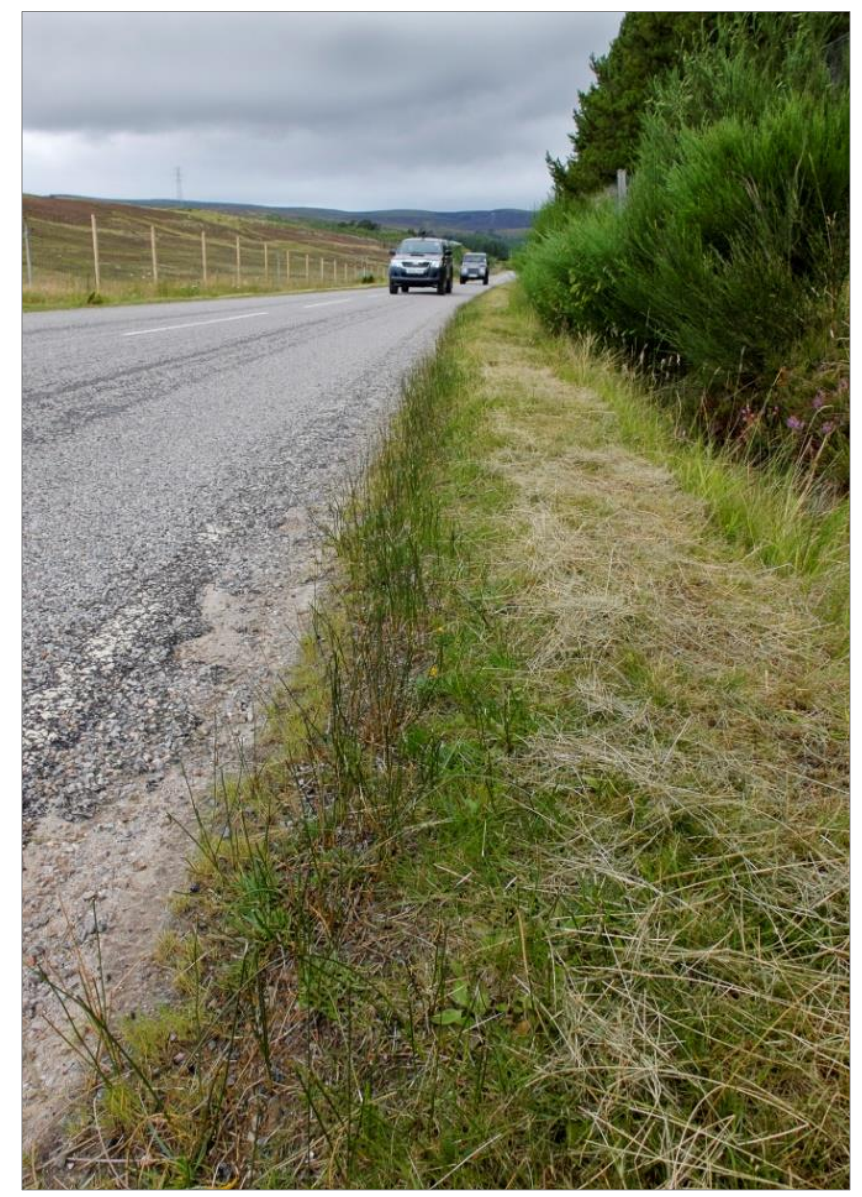

Figure 10. Juncus balticus growing on road verge, old A9, NW of Slochd (v.c.96). 


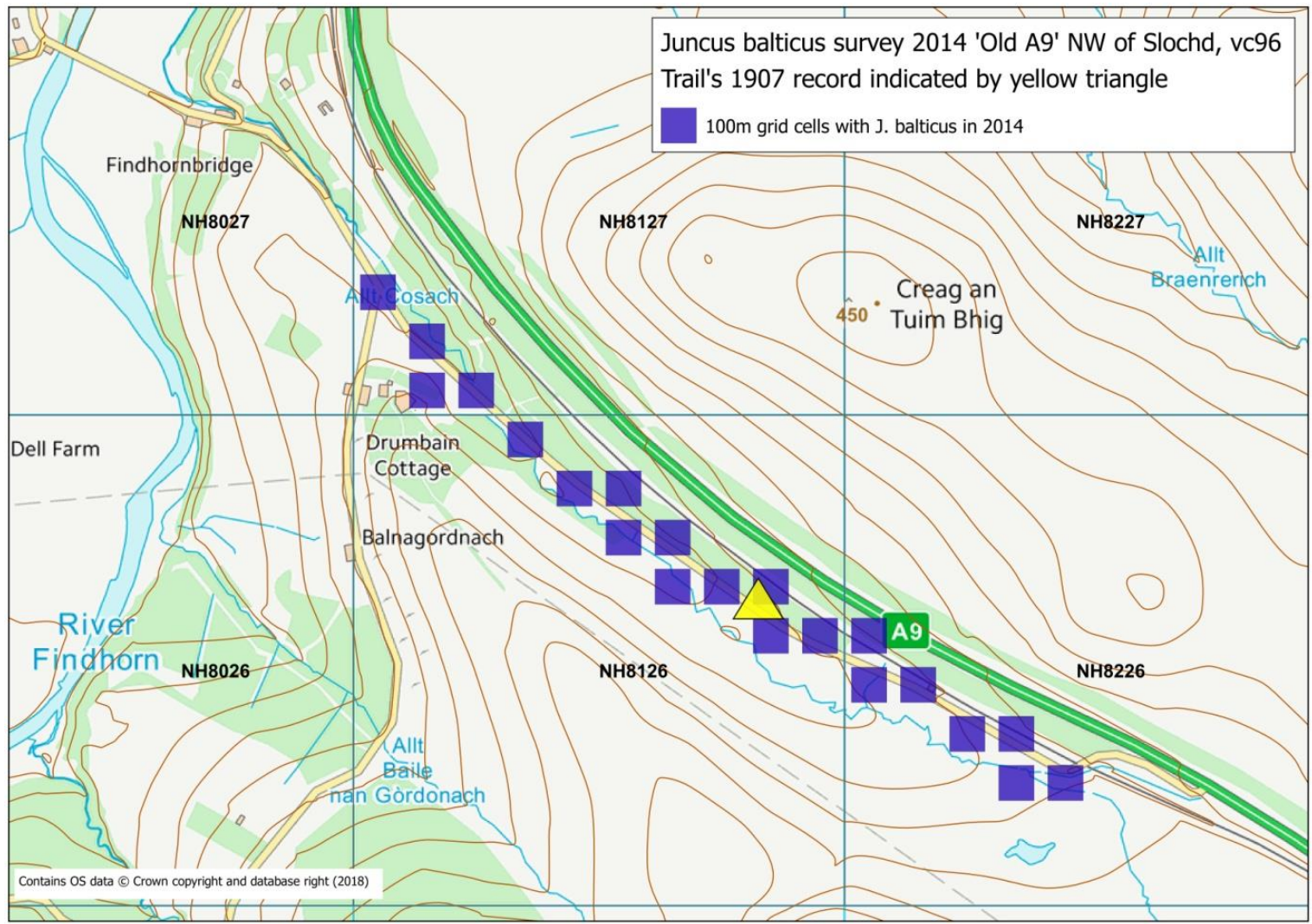

Figure 11. Distribution of J. balticus (in $100 \mathrm{~m}$ grid cells) beside old A9, NW of Slochd.

Trail's original site is $c .1 .9 \mathrm{~km}$ from the R. Findhorn, along which there are numerous populations (see above). In addition, in 1972, Mary McCallum Webster recorded J. balticus from a 'bog in gully' at Slochd. She only gave a hectad grid reference, but her site may have been in NH8424, c.3 km south-east of Trail's site. While it cannot be ruled out that $J$. balticus reached this roadside by natural spread from a nearby native population, it is perhaps more likely that dispersal was as a result of inadvertent transport of seed or rhizome fragments by people, vehicles or livestock.

It was not until 1979 that a second roadside population was discovered, by Mary McCallum Webster, beside the A941 south-east of Bridgehaugh (NJ3435) in v.c.94. In 2009 this population extended along $400 \mathrm{~m}$ of road edge at $280-290 \mathrm{~m}$ AOD. Other associated halophytes here are $P$. distans and S. marina.

In 1998, Gordon Rothero found J. balticus beside the track near to Glen Cassley hydro-works, NC3620, in v.c. 107, at $220 \mathrm{~m}$ AOD. The site is more than $60 \mathrm{~km}$ (by road) from the nearest populations at the mouth of the Dornoch Firth (v.c.107) and at Oldshoremore (v.c.108). As an assumed accidental introduction (there is a lot of vehicle traffic to and from the hydro works), this was the only hectad record marked as alien in Atlas 2000 (Pearman et al 2002). However, further down Glen Cassley, for example between NC3915 and NC4309 the habitat, from OS maps and air photos, does appear potentially suitable for J. balticus. Although never recorded there, it is perhaps worth looking for. 
In 1998, Ian Green found J. balticus growing beside the A939 in v.c.95 (NJ0920), c.3 km west of Bridge of Brown at $430 \mathrm{~m}$ AOD. Plants are now well established here, and are on both verges of the road.

In 1999, Ian Green found J. balticus at the summit of the minor road between Upper Knockando and Dallas in v.c.95 (NJ1646), at 308 m AOD. Plants were still there in 2009, when there were about 50 stems at the entrance to a track on the south side of the road.

In v.c.110, J. balticus has successfully colonised verges of minor roads (Smith, 2017), forming large clonal colonies. Richard Pankhurst made the first record, in 2000, on South Uist. Subsequently a further 10 roadside populations were detected (2011 - 2018), on Lewis, Berneray and South Uist. Nine of the ten hectads with roadside populations, have only single records per hectad. These roadside populations range from zero to a maximum of $c .7 \mathrm{~km}$ from the coast, and at a maximum altitude of $85 \mathrm{~m} \mathrm{AOD}$. The isolated nature of the occurrences suggests that there have been multiple instances of colonisation of roadsides in this vicecounty.

In $2015 \mathrm{I}$ found a dense $1.25 \mathrm{~m} \times 1.25 \mathrm{~m}$ patch of $\mathrm{J}$. balticus on the verge of the entrance road to the lower car park at Coire Cas (Cairngorm) (NH9806), at 610 $\mathrm{m}$ AOD (Fig. 12). This remarkable occurrence must be an accidental introduction, and is the altitude record for this species in Scotland. The plants had obviously been overlooked for many years (including by the author); they form a very dense patch, with a quite different jizz to typical diffuse patches.

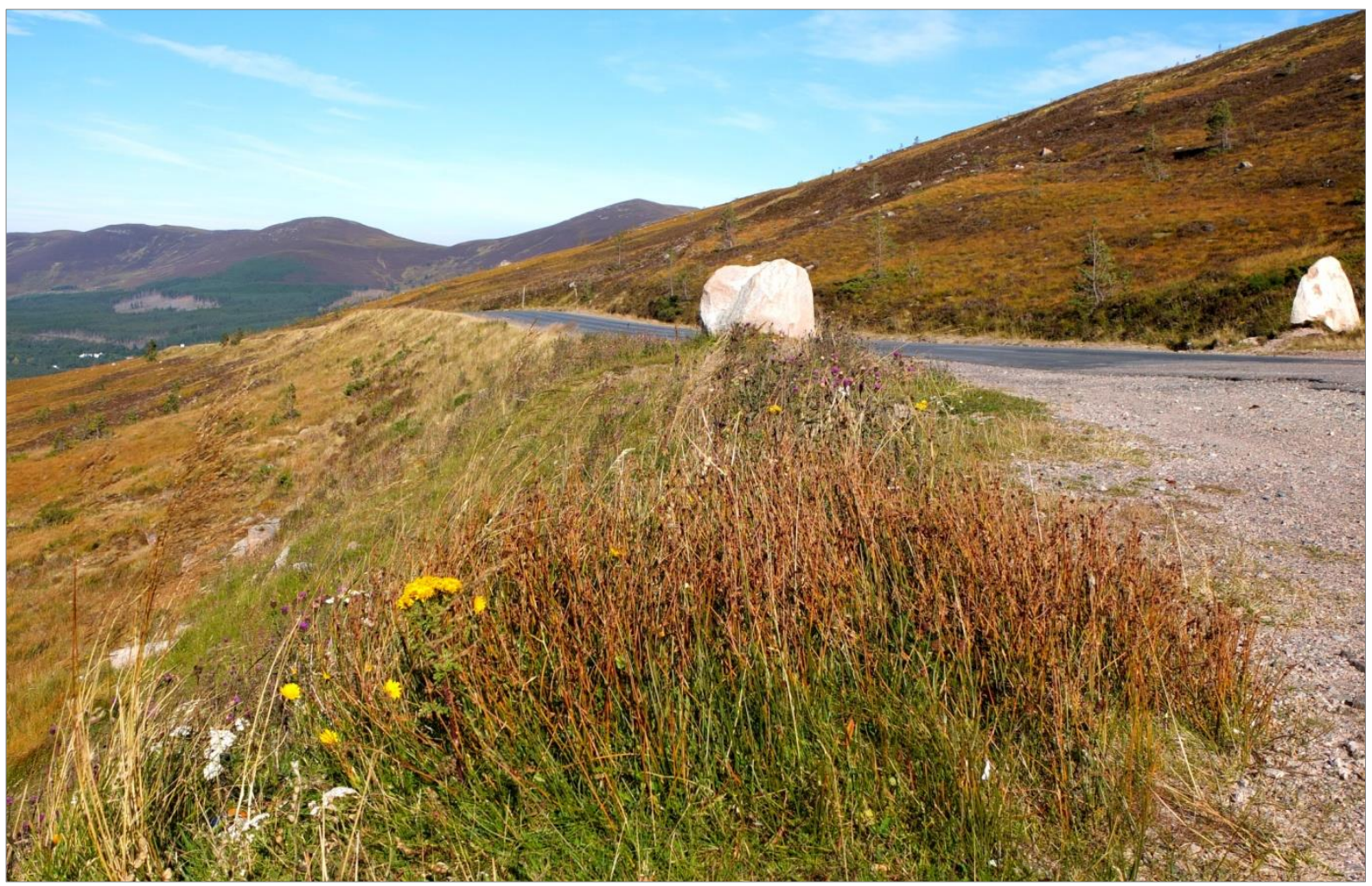

Figure 12. Juncus balticus at Coire Cas (v.c.96) at 610 m AOD.

In 2015 and 2017, Ian Green recorded small patches on the verge of the A9

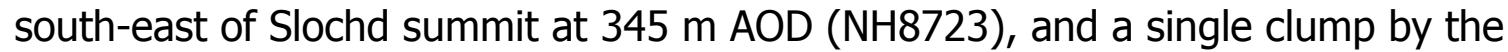


'old' A9 nearer to Slochd summit at $360 \mathrm{~m} \mathrm{AOD} \mathrm{(NH8424),} \mathrm{both} \mathrm{in} \mathrm{v.c.95.} \mathrm{He} \mathrm{has}$ also seen plants on the verge of the A9 south-west of Aviemore which appeared to be $J$. balticus (from a moving car); these are not mapped.

In 2016, Ian Evans found J. balticus on a 're-gravelled area' on a roadside at Talmine (NC5862) in v.c.108. Although within $200 \mathrm{~m}$ of the coast, the nearest known extant coastal site is $c .3 \mathrm{~km}$ away.

In 2018 a few patches were noted beside the minor road by the bridge over the Glenmazeran Burn (v.c.96) at 340 m AOD (NH7422). J. balticus occurs upstream along this burn and close by beside the R. Findhorn. The roadside plants here are most likely the product of natural dispersal.

Finally, in August 2018, en route to Sandwood Bay, J. balticus was found beside a moorland track, north of Blairmore (v.c.108), NC1960 at 90 m AOD. Here there is a patch c.4 $\times 2 \mathrm{~m}$ on the north-west side of the track, and a more extensive stand on the south-east side of the track. The nearest native, near coastal population is $c .1 .5 \mathrm{~km}$ away; the species also occurs at Sandwood Bay, c.5 km distant.

Of the 19 hectads with road or track-side populations, J. balticus also occurs as a native in coastal habitats in nine hectads and in riverside habitats in two hectads. In eight hectads it is only known from road verges where it is an unintentional introduction: these are NB32, NB34 and NB53 (v.c.110); NC32 (v.c.107); NH90 (v.c.96); NJ02 and NJ14 (v.c.95); and NJ33 (v.c.94).

In NE Scotland, within its native inland riverside range, J. balticus is recorded on roadsides from $31100 \mathrm{~m}$ grid squares in 9 monads. These roadside populations have a median altitude of $360 \mathrm{~m}$ AOD (inter-quartile range $342-381 \mathrm{~m}$ ), slightly higher than the inland riverside populations, median $290 \mathrm{~m}$ (inter-quartile range, 249 - $341 \mathrm{~m}$ ). Medians are of the mean monad altitudes.

\section{Other habitats}

Away from riverbanks and road verges, there are two inland records of J. balticus from other, probably always wet habitats.

Juncus balticus was collected at Loch of Park (v.c.91) in 1841 and 1847 (specimens at RBGE), and Dickie (1860) published a record by Dr. Francis Adams, noting that it was at the "Margin of the Loch of Park, south side". This site is in tetrad NO79U, at $70 \mathrm{~m} \mathrm{AOD}$, and lies $C .15 \mathrm{~km}$ inland. The 1901 edition (surveyed in 1899) of the Ordnance Survey 6 inch to 1 mile scale map (viewable on the National Library of Scotland website) shows the loch as open water. These are the only records from this site, and today it is a swamp of Salix and Glyceria maxima, with no open water. David Welch (County Recorder for v.c.91) considers that there is no suitable ground for $J$. balticus now or for decades past.

In 2004, Barbara Hogarth, found a small population of J. balticus at Dun's Dish (v.c.90), in tetrad NO66K, c.4 km inland, at c.70 m AOD. The plants were found in tussocky marsh/swamp, just back from the swampy margin of the lochan, towards the eastern end of the north shore. Plants were larger than those in coastal dune slacks. From Ordnance Survey maps and air photos, Dun's Dish appears similar to the Loch of Park site, though natural succession is far less advanced; open water is still present. 


\section{Discussion}

Juncus balticus is far from just being a coastal species; $23 \%$ of its recorded hectad range is inland. Native, inland riverside populations are known from 14 hectads, all in NE Scotland (Figs. 2 and 6). Most records are from beside larger rivers, the Rivers Avon, Dulnain and Findhorn. It appears to be lost from the River Lossie, where last recorded in the 19th Century. It is only recorded from beside three minor burns, tributaries of the R. Findhorn and R. Dulnain. Along the main rivers, the largest populations are at higher altitudes. On the R. Findhorn at more than $250 \mathrm{~m} \mathrm{AOD}$, on the R. Avon at $c .300 \mathrm{~m}$, and beside the R. Dulnain at more than $370 \mathrm{~m}$ AOD. Figure 9 (River Dulnain) gives an overview of 'classic' upland riverside habitat. Along these rivers lower altitude populations are small (Fig. 7), and are probably the result of dispersal by floods from source populations upstream. However, they may be very persistent, despite growing in the spate zone of the rivers. Interestingly the discovery of these populations in 1832 was only three years after north-east Scotland recorded the most severe catastrophic flood in modern UK history (Werrity and McEwen, 2003). The R. Findhorn was one of the most severely affected drainage basins, and is subject to repeated dramatic spates. It is sobering to be standing beside the R. Findhorn in its lower, gorge section, and note the flotsam hanging in trees above your head.

All post-1999 records from inland riversides have been made by the author and/or Ian Green. Judging by records on the DDb, since 1970 the only other recorders (alive today) and known to have seen J. balticus in its inland riverside habitat are Clive Stace (in 1972), Rosemary FitzGerald (in 2009, with Ian Green), and members of the Inverness Botany Group (in 1998 and 2017, the latter occasion with Ian Green). While the author and Ian Green have explored many sections of the Rivers Avon, Dulnain and Findhorn, that so few observers are familiar with seeing $J$. balticus at inland sites means it is possible that this species has been overlooked along other rivers and burns in NE Scotland, and perhaps elsewhere.

Overall, the riverside habitats in which J. balticus is found are botanically unremarkable, at least within a north-east Scotland context, having in the main, infertile, moist to damp, weakly to moderately acid soils, with high levels of illumination. The old record from Loch of Park, and a recent one from Dun's Dish, are from apparently atypical sites, as compared to other extant and historic records. This suggests that the niches occupied by J. balticus may be more varied than most recorders appreciate.

Following the early discovery of $J$. balticus on a roadside in 1907, it was not until 1979 that a second roadside population was detected. It was recorded on roadsides in five hectads pre-2000, and from an additional 14 hectads since 2000. It is now more widespread (19 hectads, all dates) on roadsides (and one trackside) than along inland riversides (14 hectads, all dates). In 12 hectads, roadside populations coincide with, or are adjacent to, hectads with coastal populations, indicating short distance dispersal. The isolated nature of these occurrences indicates that there have been multiple independent colonisations of road verges in these areas. There are also four instances where roadside populations must be the result of transport of seed or rhizome fragments over tens of kilometres (maximum 60 $\mathrm{km}$ ). It is, therefore, highly likely that additional roadside populations await discovery, and that further colonisation events will occur. 


\section{Acknowledgements}

Thanks to the following for answering queries about records: Brian Ballinger, Mick Crawley, David Earl, Sandy Edwards, Ian Evans, Barbara Hogarth, Iain Macdonald, Jim McIntosh, Gordon Rothero, Paul Smith, Phil Smith, Sarah Smythe, Clive Stace, David Welch and Peter Wortham. Liz Amphlett accompanied me on numerous searches for Juncus balticus. Pete Stroh commented on an earlier draft of this paper.

\section{References}

Adamson, R.S. 1913. Juncus balticus Willd. in England. J. Bot., Lond., 51: 350-352. Amphlett, A. 2018. Using patterns of stem stomata to differentiate Juncus balticus (Baltic Rush) from J. effusus (Soft-rush). BSBI News, 138: 38-40.

Dickie, G. 1860. The Botanist's Guide to the Counties of Aberdeen, Banff, and Kincardine. Aberdeen: A. Brown \& Co.

Hill, M.O., Preston, C.D. \& Roy, D.B. 2004. Plantatt. Attributes of British and Irish Plants: Status, Size, Life History, Geography and Habitats. Monks Wood:

Biological Records Centre. NERC Centre for Ecology and Hydrology.

Hooker, W.J. 1821. Flora Scotica. London: B. White.

McCallum Webster, M. 1978. Flora of Moray, Nairn \& East Inverness. Aberdeen: Aberdeen University Press.

Pearman, D. 2017. The Discovery of the Native Flora of Britain \& Ireland.

Dorchester: BSBI.

Perring, F.H. \& Walters, S.M. 1962. Atlas of the British Flora. London: Thomas Nelson and Sons.

Preston, C.D., Pearman, D.A. \& Dines, T.D. 2002. New Atlas of the British and Irish Flora. Oxford: Oxford University Press.

Smith, P. 2017. Some interesting salt-tolerant plants of roadsides in the Outer Hebrides. Hebridean Naturalist, 16: 15-23. Available from https://eprints.soton.ac.uk/403520/.

Smith, P.H. 1984. The distribution, status and conservation of Juncus balticus Willd. in England. Watsonia, 15: 15-26.

Stewart, A., Pearman, D.A. \& Preston, C.D. 1994. Scarce Plants in Britain. Peterborough: JNCC.

Werrity, A. and McEwen, L. 2003. The muckle spate of 1829 - Reconstruction of a catastrophic flood on the River Findhorn, Scottish Highlands. In: Thornycroft, V. R., Benito, G., Barriendos, M. and Llasat, C., eds. (2003). Palaeofloods, Historical Floods and Climatic Variability: Applications in Flood Risk Assessment (Proceedings of the PHEFRA Workshop, Barcelona, 16-19th October, 2002). Madrid: Centro de Ciencias Medioambientales, pp. 125-130. ISBN 9788492195824 Available from: http://eprints.uwe.ac.uk/20347

Copyright retained by author(s). Published by BSBI under the terms of the Creative Commons Attribution 4.0 International Public License.

ISSN: $2632-4970$

https://doi.org/10.33928/bib.2019.01.202 